for the Quagga. Very interesting in this connection is the report by C. G. IIahn, Native Commissioner Ovamboland, Ondangua, published in our Journal, No. XXXIX, of April, 1940.

Red Deer.- The British Field Sports Society informs us that they have drafted a bill to deal with the protection of deer in Scotland. Their opinion is that it would be best to get the bill for Scotland through before considering the position of the English deer.

\title{
REPORT ON A VISIT TO EAST AFRICA
}

\author{
By Captain Keitir Caliowell
}

(Late of the Kenya and Uganda Game Departments)

I reached Nairobi on 29th December, 1950, and left on 4th May, 1951, after covering about 4,000 miles. With the exception of a visit to Dar-es-Salaam the whole of my time was spent in Kenya.

I should like to express my thanks to the Government of Tanganyika for their kindness and also for the patience with which they have borne with me and, once again, to the Game Department of Kenya for acting as my godparent.

Kenya.

I am glad to say that Captain Ritchie, whose retirement became effective last October, has almost completely recovered from his serious illness. His great knowledge and wise counsel will always be at the disposal of his successor Mr. William Hale.

To the latter I am indebted for continuous help and kindness during all my time in Kenya. He faces a difficult task. More and more land is required for development--more and more complaints pour in on account of genuine or alleged damage by animals--morc and more problems arise daily.

The general attitude toward game in Kenya-taken by and large-continues to be good.

The new Kenya Game Ordinance has at last become law, and even if not perfect (what Game Ordinance ever is?), is an immense improvement on its predecessor.

I am indebted to the editor of The Field for permission to reproduce the following comments which I wrote just after leaving Kenya :--

The Legislative Council of Kenya has just passed a "Wild Animals Protection Ordinance" which will, it is expected, come into force within 
the next two months. This law is, in effect, a new cdition of the old "Game Ordinance". The title has been changed partly because some folk always seem to connect the word " game " with millionaire sportsmen, pheasant battues, and the like, and partly because the new ordinance embraces a wider scope than the one it replaces. The problems attending conservation are constantly changing, thus new legislation, to meet postwar conditions, was urgently needed.

The Royal Game List (i.e. animals completely protected throughout the colony) has become formidable. Old friends such as Thomas' Cob, Yellowbacked Duiker, Aard Wolf, Pangolin, and the rest reappear, and to them have been added a whole series of birds. Why this has been done is not very clear since all of them are plentiful and, more important, I have never heard of anyone wanting to shoot them. The Bat-eared Fox has also entered the list. This charming little animal has never previously been scheduled at all. It is very common and one would not have thought it necessary to make it Royal Game. Roan Antelope, now becoming very scarce in the colony, get complete protection, as do female cland. The cland, though it carries a poor trophy, has alas a great moat value and accordingly has suffered severely. In future only males may be shot, and only one on a full licence at that.

Leopard join elephant, rhino, and other animals for which a special licence ( $\$ 10$ in this case) will be needed. In the old days leopard were vermin; then, as their skins became of greater value, they were put on a licence, first in unlimited numbers and finally as "one only". The action came almost too late. In many areas leopard were nearly exterminated, and as a result baboon, safe from their normal predators, multiplied enormously. It is hoped that putting leopard on an expensive special licence will give them the extra protection they require to enable the balance of nature to be restored.

The price of visitors' full and fourtee'i-day licences has been reduced by $33 \frac{1}{3}$ per cent, i.e. to $£ 50$ and $\$ 10$ respeetively, but the cost of an Elephant licence has gone up for all to $\$ 75$ for the first elephant and $£ 100$ for the second. Kenya has the biggest ivory in Africa and rightly does not intend its acquisition to be too profitable to the shooter. The fee for a Rhino Licence has, I am glad to say, risen from $£ 10$ to $£ 15$.

A new clause in the ordinance states that if an elephant or rhino is wounded but not killed it shall count upon the shooter's licence, and a further salutary section makes it compulsory to report the wounding of any dangerous game animal. Failure to do so is an offence for which imprisonment with or without a fine is mandatory. The present Kenya Game Ordinance prescribed this severe penalty for any offence where rhino were concerned. The result has been admirable and far more rhinoceros are now seen than formerly. Opposition to this clause, largely inspired I fear by those whose activities were circumseribed, has unfortunately been successful and has caused its omission from the new ordinance.

At last the meat hunter has been faithfully dealt with. The biltong trade is one of the most difficult to control ; once an animal is cut up and dried out it is almost impossible to know what it is or how many beasts are represented in a lorry load of dried meat. The meat hunter always has a ready explanation: "My licence allows so many of this and that and the other. Here they are." The new ordinance gives power to control the movement of dead game, and an order is about to be drafted 
forbidding the removal of more than a certain quantity of fresh meat and any dried meat out of any of the five principal game areas in the colony.*

An admirable and wise innovation is designed to give native authorities a genuine interest in their own game. Certain districts will be known as "Controlled Areas" and quite a considerable fee, additional to the licence, will be charged for each animal killed therein. The money is to go to the African District Councils, and it is hoped that they will connect cause and effect.

Directions will be issued to licensing officers laying down the qualifications necessary to obtain any particular licence and the type of weapon that may be used. The former of these directions will, I hope, put an end to the happy method whereby the applicant for an elephant licence used also to take out one for his sister, his cousin, and his aunt and then go off and kill four elephants, whilst the actual licence holders sat quietly in camp. The latter direction will prevent obviously unsuitable rifles, e.g. low velocity $\cdot 22$, being used against game.

Penalties have gone up, and the maximum fine for the majority of offences is to be $\$ 250$ instead of $\$ 100$.

Drafting game legislation is a very difficult and tricky thing. No matter how carefully one sets about it, it is impossible to foresce every eventuality and slips may so easily occur. As an example, the "onus of proof" section has, I am sorry to say, been left out of the new ordinance. I rather fancy the clause as first drafted was dropped as being too general, and by accident a modified clause was never substituted. In this instance, broadly speaking, the "onus of proof" clause means that if anyone is charged with illegal possession of any trophy it is up to him to prove he got it legally. Without such a clause the Game Department has to prove the accused got it illegally, a very different thing and not always easy to do. Witness the following. Many years ago, acting on "information reccived", we caught a Somali trader with a camcl safari making for the border as hard as he could go. In the camel mats were found $\mathbf{1 5 0}$ rhino horns. He was charged with "illegal possession ", got two years' imprisonment, and the horns were confiscated. In due course he appealed, and it was held that the Game Department had to prove that he had obtained the horns illegally. This was, of course, impossible, with the result that his sentence was quashed and, worse, the horns had to be returned to him!

I hope no one will think I am criticizing. Game legislation is full of pitfalls and we have all fallen into them at some time or other. In the early twenties ten buffalo were allowed on a licence, and since their hides were of considerable value for native shields they were heavily hunted, and quite a lot of "browning" of herds took place. To stop all this we amended the schedule of what might be shot to read buffalo ten, "males only," but quite forgot to put cows on the Royal Game list at the same time. The actual result was, of course, that the luckless cows became vermin! I am glad to say that no one, not even defending atvocates, ever spotted this and we got convictions against a number of offenders.

The new ordinance, taken as a whole, is an immense improvement on any of its predecessors. A few snags are sure to appear but it does, at last, make it possible for the Game Department to get on terms with the

* By order issued on 5th .July, 1951, the amounts are fixed at $200 \mathrm{lb}$, of fresh meat and $20 \mathrm{lb}$. of dried meat. 
man who takes out a licence to make a profit, and yet gives the genuine sportsman a good run for his money.

Wild life is disappearing and must, of course, continue to disappear wherever it conflicts with development. One of the chicf aims of conservation is to retain it unimpaired in areas where it does no harm. I hope and believe that the new Kenya Game Ordinance will be suceessful in achieving this end.

The Trustees of the Kenya National Parks have paid me the great compliment of appointing me an Honorary Trustee. I was thus able to make a comprehensive visit to the Tsavo National Park under what I would deseribe as " red carpet" eonditions. The Director, Colonel Cowie, gave me every assistance, as did Messrs. Taberer and Sheldrick, the wardens of the west and cast sections.

I was greatly impressed with what has been done in the short time that the park has been in existence.

I spent a week on safari in the Tsavo area and was astonished at the progress in the last two years. Several hundred miles of amazingly good tracks now give visitors access to country which a couple of years ago had hardly been seen by Europeans. Game, other than elephant and rhino, is not what you would call obtrusive; in fact, if unlucky one may go a long way and see very little, but the policy of improving water supplies will, I hope, here, as in the Wankie Reserve in Southern Rhodesia, lead to a very considerable increase in the ungulates.

The park has two (and will doubtless, as time goes on, have many more) most spectacular features, to wit Mzima Springs, in the western half, and Mudanda Rock, in the east.

At Mzima Springs visitors can stand on a platform and look down into water so gin clear that they can see and even photograph hippo swimming completely submerged. Most folk who have travelled widely in Africa have seen numbers of hippo, but I will wager very few of them have seen every detail of these bcasts under water at their feet.

The editor of Country Life has kindly allowed me to reproduce extracts from a short article I wrote after several visits to the water hole at Mudanda Rock :-

The rock runs nearly north and south; the water lies on the north-east side and the prevailing wind is east, so that there is no danger of spectators bcing given away by scent. Elephant, especially old bulls, may come down to drink at any time during the day but the star performance generally starts about 4 p.m. The bush opposite the rock gradually fills up with slow moving grey forms wandering down to the water hole until anything up to fifty or sixty can be seen drinking together with numbers of others waiting their turn. They come all sizes and shapes, fathers, mothers, and young. The heads of families go in a few yards and stand sedately, usually 
with one foot lifted, whilst they quench their thirst. Children scuffle round mothers, get in the way of their elders, and now and again are chastized by irritated cows. Bulls occasionally have words and "shape up" to each other, but nothing much comes of it. A few elephant, but only a small minority, lie down to a real bath and get up looking black and dressy ; others scem content with simple mud behind the cars.

The drinking parties go on till dark and later. Batch after batch of animals follow each other to the water and it is by no means unusual to see $300-400$ elephant in the course of an evening. Now and again a rhino tries to join the party. If he is wise enough to get into the water well down wind he will probably get away with it, otherwise he is usually seen off by half a dozen elephants which advance towards him with cars forward. Once in a way the rhino will retaliate and push the elephants back, but this is, I fancy, unusual. There is a good deal of face saving about these water hole demonstrations and $I$ doubt if the contestants often come to grips, although a rhino was recently ripped open and killed by a hippo in another part of the Tsavo Park.

One of the most astonishing things about Mudanda Rock is that although it lies only about three miles from the Mombasa-Nairobi line, nothing scems to have been known of it by Europeans until the late nineteen twenties when a few sportsmen came across it and naturally kept very quict about their discovery. It is not the sort of place one would find easily without guides, and the local hunting tribes who had used it for gencrations took care to keep it a close preserve.

'Times have changed. For travellers motoring to or from Mombasa the new roud past the rock adds only two or three miles to their journey. As a recompense they will, if they go there at the right time of year, see a sight which is as unforgettable as it is unique.

Accommodation is gradually being arranged for visitors and a fair-sized camp with bedrooms, baths, and a messing hut has been completed. The excellent tracks to which I have referred (400 miles of them) have brought problems in their train for they cannot be patrolled every day and there is always the danger of a car breaking down "in the blue". The passengers might or might not know their way back; moreover, if they decided to face the walk they might, or might not, meet elephant or buffalo, to say nothing of an odd rhino on the way. It is not feasible to check folk out as there are a number of exits, and it will, I think, be necessary to confine the majority of visitor's cars to certain main tracks or make them go in convoy. Those who demur will have to hire a native seout to go along with them. The visitor will probably have no Swahili and the scout almost certainly no English, but the latter will at any rate be able to find his way back to a Ranger Post and in time bring up help.

A certain amount of poaching, chiefly by Wakamba and Waliungulu, takes place in the park. These people travel very light and since they rcalize that the Rangers won't use their 
rifles, wisely refuse to stop when called upon. They are thus excecdingly difficult to catch, but taken by and large I doubt if they do serious damage.

Nairobi National Park.

The Nairobi National Park remains as popular as ever and the amount of game one sees and its tameness is quite remarkable. Giraffe, for instance, often take up a stand in the middle of the road and make no effort to move until one starts to edge a car past them.

The standard of behaviour of visitors has much improved, although the congenital idiot, who will get out of the car in order that "the dear children" can get a nice close up of the lions, is still with us. These beasts are as great a draw as ever, but they are presenting problems of their own. In spite of the great amount and variety of food available for their delectation within the park they have shown an increasing tendency to squeeze through the barbed wire boundary fence and hunt donkeys, cattle, and the like outside. No one (or at any rate very few people) want lions in their back garden or killing their stock. In places the popularity of these cats has waned.

Unless some means can be devised of keeping the lions within the park there is serious danger that they may have to be destroyed.

On my way to the Tsavo I camped in the Southern Game Reserve on the Makindu River. As a result of the creation of the new National Park it has been decided to do away with most of the old reserve, retaining only such portions as have a special faunal value, e.g. an area near Lake Amboscli on the Tanganyika border and, if possible, a small patch near Makindu.

To many the idea of breaking up the Southern Game Reserve, after 50 years as such, will come as a shock, but a great deal of it, from a conservationist point of view, has very little value. As I have so often pointed out, a reserve that is a reserve only in name is worthless.

Until recently no one had been available to police the castern side of the area, with the result that the Wakamba, who live just over the boundary and have more or less exterminated the game in their own country, considered it a delightful hunting ground.

Near my camp I found three large heaps of bones in quite a small area. These relics of Wakamba poachers had been collected by an enterprising Indian who found it worth his while to take them by lorry to Nairobi. The skulls showed that 
eland, hartebeeste, impala, Cirant's gazelle, and zebra were chicfly represented, with an odd giraffe and buffalo.

In order to deal with ivory poaching on and near the Yatta Plateau a Game Department Officer has been stationed at Makindu and has been able to keep an eye on the corner of the reserve near by. The result is most encouraging. In an cvening drive of a few miles along good tracks close to the main NairobiMombasa road one is sure to sce a variety of plains game beside giraffe and lesser kudu and, most interesting of all, half a dozen or so rhino wandering out on the open plain. Buffalo and clephant are found at times.

It scems very probable that this little haven will be required to provide additional grazing for the Wakamba tribe, who will doubtless be highly gratified to find so much wild life in their new abode and, as is their wont, will waste no time in destroying it.

Provided that this land is genuinely required for development it will, I suppose, have to be taken, but I confess I would like to be convinced that no alternative area is, or can be, made available.

After refitting in Nairobi I did a safari of about 1,200 miles in the Northern Frontier District. Owing to the failure of the short rains water was very scarce and game was accordingly concentrated. The country I first visited had been extensively used as a training ground by the King's $\Lambda$ frican Rifles and the behaviour of such wild animals that were left showed their full appreciation of this fact. The odd zebra (there were very few) cleared off at 800 to 1,000 yards on sight of a lorry yet, as a friend who was with me proved, they could easily be approached to within 100 yards by a careful stalker on foot. Never before have I scen guinea fowl take to the wing when they spotted a motor vehicle a quarter of a mile away. Steps are being taken to deal with the situation. All bird shooting has been prohibited over a large area and additional Game Department stafl have been posted to the district. Shortly before my visit a British N.C.O. was found with a dozen or more game carcases-oryx, Grant's gazelle, waterbuck, and the like-in an army lorry. He had no licence (not that any licence would have covered this pile) and was, I am glad to say, fined 140 . I hope that this case will act as a salutary example and that the widespread abuses of the past will abate. 
Further afield game, especially elephant, appeared much more plentiful but it was diflicult to be certain owing to the drought. I have never seen the land so dry. Sandgrouse, driven to desperation for their morning drink, would show complete disregard for man and great flocks would water at one's feet as one stood in the open.

To the east conditions were much worse, as the lower part of the Northern Uaso Nyiro and the Iorian Swamp into which it flows dried up. I think the following report, made on the 23rd March by the Assistant Game Warden of the area, is one of the most interesting I have ever read :--

\section{SITUATION ON THE L,ORIAN SWAMP}

I arrived at Habaswein on the afternoon of the 18 th and was there until the 21st. During these four days $I$ tricd to sec as much as possible of the conditions caused by the severe drought. It was a truly appalling experience; during all my many years of experience of the country $I$ have never seen anything more grim and pathetic. Everywhere in and around Lorian the air was heavy with the stench of death and corruption, decaying earcases, and the bodies of dying animals, mostly sheep, goats, cattle, and camels lay around, thickest beside the somali bomas paths and water holes. The swamp had completely dried up. The tribesmen had dug wells in the bed of the river and in the middle of the swamp, which got deeper as the water receded, until in the end there was not enough to keep their stock watered in spite of day and night labour. Many of the people in desperation had left with their flocks and herds heading for the wells of Wajir, over 60 miles to the north, hoping to get through. Probably their plight was worse than that of those who had stayed behind. It can be imagined what the sufferings of the wild animals have been, unable to get at the water in the wells and without a drink for over a month. Along the river bed I saw the dried-up carcases of dozens of Grevy's zebra, obviously they had become borged in the mud before it dried up and had died more from exhaustion than thirst. One dried-up mud hole contained the bodies of two elephants and a little calf; beside them lay a camel still alive cemented into the dry mud. I was told that it had been there for over a month. Another hole of still liquid mud was filled with the rotting carcases of dozens of goats, sheep, and cattle and the wriggling forms of hundreds of eat fish. At the Sabenna water holes, which lie roughly in the middle of the swamp, I was told that as soon as it got dark elephants would come and fearlessly push their way through the waiting stock and drink the water out of the clay troughs as the tribesmen filled them. One in particular had been troublesome and had killed a number of cattle. I waited up for him and, sure enough, along he came soon after dark. He paid not the least attention to the yelling Somalis, who greeted him with a shower of sticks and clods of earth, and started to make a round of the troughs. Obviously he was dangerous and had to be shot and killed with a brain shot. There were too many pcople around to risk a body shot which might not bring him down immediately. After a deal of manocuvring I managed to get close up to him across the mouth of a well, and while my wife held a torch 
I put a bullet through his brain. I was also told that the men and women working in the wells dare not leave for their villages until their clothes had dried as the clephants would scent the water and give chase. Women carrying water would often have to throw down their pots and fly for their lives while the elephants smashed up the conlainers. On another occasion an clephant trying to get at the water in a well caused the sides to fall in, burying the three men who were working below. Fortunately, they were rescued. The situation seemed hopeless, and all that could be done was for me to wait at the Lorian and protect the people at the wells and collect the ivory of the elephants as they died. Up to this time, eleven elephants had died, from which sixteen tusks had been recovered, six having been stolen. A police patrol returning from up river brought in seven tusks of elephants which had died of thirst and reported that gangs of Boran youths had speared several more and stolen the ivory in the neighbourhood of Cabatu.

Fortunately, on the morning of the 2oth, the river came down in flood and the situation was saved.

I don't fancy many folk would have managed to kill an elephant with one shot under such conditions, nor that many women would have held a torch steadily enough to enable the job to be done.

In general, the Northern Frontier District has changed but little. It will, I am sure, be the last stronghold of game in Kenya outside the National Parks. Wandering in its vast arid spaces one can-if one keeps off the beaten tracks-still see Africa as it was in the beginning, unimproved and unspoilt.

I confess it gives me a shock to hear details of a new rest camp (put up, I understand, for a film company) in the heart of the Masai country where every bathroom is equipped with a "pull and let go", or to meet a "Coca Cola" van on the Northern Uaso Nyiro.

\section{T'anganyilia Territory.}

In my report, written in 1947 , I painted a very gloomy picture of game conditions in 'Tanganyika, but in $1950 \mathrm{I}$ stated that after an interview in London with Sir Edward 'Twining, the new Governor of Tanganyika, I was confident that game problems that came before him would be "fully examined and fairly judged ".

These words have been justified. The alteration in the general attitude toward wild life in this territory is almost incredible to those who had experience of previous conditions.

Looking back I feel it very probable that the state of alfiairs that existed was largely a result of the aftermath of the war and that the Government, fully occupied with other matters, did not realize what was going on. 
Everything has now changed. Genuine sympathy toward game - in its proper place-exists on all sides, both in official and unofficial circles. Moreover, such sympathy has been translated into very effective action.

'The Serengeti National Park, which at one time looked like being pared down to the Nooro Ngoro (rater, has been restored to something like its original size. It is true that some hundreds of square miles of the Upper Duma Valley have been excised for the benefit of the Wa Sukuma but it was a matter of give and take and the area could fairly be spared. The park boundaries have now been finally gazetted and its administration is in process of being transferred to trustecs.

The staff of the Game Department has been greatly increased and they now have some chance to compete with law breakers.

Finally, a workable ordinance has been drawn up and has, I expect, by now become law. By the courtesy and generosity of the Tanganyika Government I was invited to Dar es Salaam to attend the Select Committee of Legislative Council, who were considering the draft Bill. I had already been privileged to see and comment on the carlier draft, and a short memorandum I had submitted was before the committee.

I am most grateful to the committee for having allowed me to take part in their deliberations and for their patience in listening to my views.

The keynote of the discussion was the desire to co-operate and to be absolutely fair to all the interests affected. No conservationist could ask for more.

In general, the ordinance is a vast improvement on the one it replaces. Not only has a genuine effort been made to put the meat merchant out of business but also the uncontrolled and unlicensed native hunting, permitted under the old law, has been stopped and replaced by a limited inexpensive native licence. No one, I fancy-certainly not I-imagines that this will stop natives hunting illegally, but it will cramp their style ; moreover, it gives the Game Department a chance to get on with the job without having their hands tied.

Major M. Moore, V.C., for many years Game Warden, has now retired and has been suceceded by Mr. G. II. Swynnerton. The latter has served in the Department for some time and has a very complete knowledge of the country and its problems.

Major Moore's services will not be lost for he has been appointed a trustee of the ncw Serengeti National Park. Mis unique knowledge of the area for which he has done so much will be a very valuable asset. 


\section{Uganda.}

The information regarding this country is depressing. It appears that over most of the Protectorate game, oulside the reserves, is almost finished.

There is some left in a fow small pockets in the Western Province and throughout Karamoja, especially near the Sudan border, but elsewhere very little indecd.

Much has, of course, been destroyed by the Tsetse Control, but only in certain defined areas; most of the decrease is, without question, due to illegal killing by natives.

It appears that no less than $120 \cdot 303$ rifles were recently stolen from the police. These weapons have been a joy to poachers who, having cleaned up what was left in Buganda, are now moving further aficld. Kob, hartebeeste, and such beasts as waterbuck are the worst sufferers for the simple reason that they carry most meat.

In the Acholi country, where one chief claimed $4,+13$ head killed by his people in $\mathbf{1 9 4 8}$, authorized tribal hunting is stcadily reducing what game is left. As I said in a previous report, it would be interesting to know the total number of game animals killed annually in the tribal hunts.

Lest it be said that I am putting forward an ill-founded and biased view I would like to quote the following extract from the East African Standard of 18th May, 1951 :-

The future of game remaining in Cganda will be "gloomy indeed", says a Secretariat statement, unless urgent action is taken for stricter control of hunting, better policing of game reserves, and the creation of national parks.

Information reaching the Protectorate Government shows that in areas over which sast herd, of game once roamed little is now left except bush buck, pig, and baboon.

In 1925 it was estimated that there were 18,700 elephants in Iganda. By 1950 the figure had been reduced to about 8,000 .

During those 25 years, 25,892 elephants were killed by (iame Department staff on control operations and 7,650 by licence holders.

In 1950 a record number of elephant licences were issued at total of 699 .

Of the elcphants remaining in Cganda, most are said to be cows and calves, accompanied by immature bulls. Most of the bigger bulls which have survived normally eling to the game reserves.

Buffaloes are still the most numerous of any of the game animals in the Protectorate. They inerease and multiply despite every sort of setback.

Antelopes have suffered very badly from excessive tribal hunting, poaching with unlicensed $\cdot 303$ rifles, and with shotguns.

In Buganda, in particular, antelopes of all species have been almost exterminated. 
Outside the game reserves there are few Uganda Kob left, and it is probable that within the next ten years these will be cxterminatod.

'The gorilla and the white rhino are quite safe. White rhino especially are showing a satisfactory increase.

Since this is the official view, the picture I have drawn cannot be considered cxaggerated. As regards elephant, however, it is hard to reconcile with the (novermment estimate of " not less than $16,000 "$ published in 1950 .

\section{National Parks.}

No National Park has yet becn declared in Uganda, but a National Parks $B$ ill has appeared and a committec was appointed to make specific recommendations. It reported in 1950 and advised that the following areas should forthwith be proclaimed National Parks :-

(a) Mount Ruwenzori, from the forest line upwards. Contains very little game but has great scenic and floral attraction.

(b) Katwe--A plains area which has for long been a game reserve. It is casy of access, very spectacular from a faunal outlook, and is admirably suited as a National Park.

It was never intended to proclaim more than 150 square miles of the rescrve, but even this has been halved. The Paris Committee describe the result as " not as large as we could wish". I agrec.

(c) Murchison Falls.--It is hoped that an area of up to about 300 square miles will be available. The district is fimous and has great faunal and spectacular value.

(d) A small park of about 13 square miles to link up with the Gorilla Sanctuary in the Belgian Congo.

The committee also recommended certain additional arcas for future consideration.

It is hoped that the necessary legislation will be passed in time for some, at least, of the above to become National Parks by the beginning of 1952 .

There are one or two brighter spots. Game in the reserves seems to be holding its own and the White Rhino, which have been carefully cherished, are on the increase, as are gorilla. Buflalo look after themselves with greal success, and my sympathy goes out to those who have to try and control them.

There is, I am glad to say, reason to think that the Uganda Government is beginning to realize that a Game Department has other functions to perform beside the admittedly essential one of control and that, in future, sufficient staff will be available 
to enable a modicum, at least, of preservation to be carried on. Additional staff is only one of the needs. The Protectorate requires a completely different mentality where wild life is concerned. The Gallio-like atmosphere, in which it has hitherto been stecped, needs to be replaced by a healthy public opinion; Game Laws should be properly and strictly enforeed and not relaxed by irregular exemptions or tacit permissions. In addition penalties should have some relation to the profits made by the wrongdoer. It is farcical to fine a man 5s. when he has just sold illegally killed meat to the value of $£ 5$.

Finally, it must be realized that wild life in general should be conserved as an asset and not merely squandered as a contribution to the revenue.

The only year when the Department failed to make a profit was in 1949. The loss in this casc was entirely due to expenditure on economic lisheries.

An examination of the staff position in that year is interesting. There were six European Field Oflicers in the Game Department - three on lishery work and three on elephant and buffalo control.

In addition, 99 natives were employed, as under :-

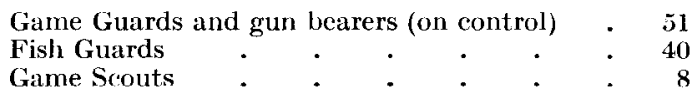

The administration and police have always co-opcrated closely with the Game Department and given ready and invaluable assistance, but in view of their many other duties the help they can give is limited.

Similarly, the European Game Rangers and their Game Guards devote, I am sure, such time as can be spared to the work of general game preservation, but the fact remains that their primary duty is to deal with animals that arc doing damage.

There you have it. Out of a staff of over 100 the work of policing the reserves, supervision of hunting, and detection of oflences was supposed to be carried out largely by three part-time Europeans and eight Africans.

Small wonder that the Secretariat statement I have already referred to remarks that little is now left except bush buck, pig, and baboon.

The situation can be changed. Signs are not wanting that the Uganda Govcrnment intends to change it and is starting to take the necessary steps to do so. 


\section{European Conference.}

The day after my return from Kenya I flew to The Hague to attcnd a meeting of the "Conseil International de la Chasse" and presided at the discussions of the "Commission de la Chasse aux Grand Faunes ".

Like all similar bodies, it has become almost entirely conservationist in its aims and, moreover, exerts very considerable influence amongst European governments, three of which belong to it officially.

I was very glad to meet Colonel Bourgoin, who has been appointed Chief Game Warden of all French Overseas Territories and is rapidly going ahead with the task of creating Game Departments throughout the various colonies.

It is most satisfactory to find that at long last the French and Belgian Colonial Governments have realized the value of wild life conservation outside, as well as inside, national parks and are taking the question seriously.

The newly created Game Departments should do much to control certain well known abuses which have continued for so long.

\section{General.}

It can fairly be said that in Kenya and Tanganyika the game situation is not unsatisfactory.

National Parks have been proclaimed and are being developed. Game Departments have been enlarged and new and up to date legislation has been enacted.

At last attention is being paid to the research side of game conservation, and the appointment of a qualified zoologist to the various African Game Departments has been accepted in principle.

In addition plans are under consideration for a complete team (biologist, veterinary research officer, ecologist, and game ranger) to undertake an extended faunal survey in Northern Tanganyika, where adequate material is easily available.

The information that will accrue from this survey will be invaluable and will enable the future work of the various game departments to be carried out on a proper basis. 